\title{
Religious diversity, ecology and grammar
}

\begin{tabular}{|c|c|}
\hline $\begin{array}{l}\text { Author: } \\
\text { Hermen Kroes }\end{array}$ & sbergen $^{1}$ (I) \\
\hline $\begin{array}{l}\text { Affiliation: } \\
{ }^{1} \text { Department } \\
\text { and Christian } \\
\text { of Theology a } \\
\text { University of } \\
\text { Pretoria, Sout }\end{array}$ & $\begin{array}{l}\text { of Dogmatics } \\
\text { Ethics, Faculty } \\
\text { nd Religion, } \\
\text { Pretoria, } \\
\text { h Africa }\end{array}$ \\
\hline $\begin{array}{l}\text { Research Proj } \\
\text { Project Leade } \\
\text { Project Numb }\end{array}$ & $\begin{array}{l}\text { ect Registration: } \\
\text { r: J. Buitendag } \\
\text { er: } 02402343\end{array}$ \\
\hline $\begin{array}{l}\text { Project Descri } \\
\text { This research } \\
\text { project, 'Theo } \\
\text { Nature', direct } \\
\text { Dr Johan Buit } \\
\text { Department o } \\
\text { Systematic Th } \\
\text { of Theology, L } \\
\text { Pretoria. }\end{array}$ & $\begin{array}{l}\text { iption: } \\
\text { is part of the } \\
\text { logy and } \\
\text { ted by Prof. } \\
\text { endag, } \\
\text { f Historical and } \\
\text { eology, Faculty } \\
\text { Jniversity of }\end{array}$ \\
\hline $\begin{array}{l}\text { Correspondin } \\
\text { Hermen Kroes } \\
\text { hermen.kroes } \\
\text { gmail.com }\end{array}$ & $\begin{array}{l}\text { g author: } \\
\text { sbergen, } \\
\text { sbergen@ }\end{array}$ \\
\hline $\begin{array}{l}\text { Dates: } \\
\text { Received: } 27 \mathrm{~A} \\
\text { Accepted: } 07 \mathrm{~J} \\
\text { Published: } 04\end{array}$ & $\begin{array}{l}\text { Apr. } 2020 \\
\text { July } 2020 \\
\text { Sept. } 2020\end{array}$ \\
\hline $\begin{array}{l}\text { How to cite th } \\
\text { Kroesbergen, } \\
\text { 'Religious dive } \\
\text { and grammar' } \\
\text { Teologiese Stu } \\
\text { Theological St } \\
\text { a6064. https:/ } \\
10.4102 / \text { hts.v }\end{array}$ & $\begin{array}{l}\text { nis article: } \\
\text { H., 2020, } \\
\text { ersity, ecology } \\
\text { ', HTS } \\
\text { idies/ } \\
\text { udies } 76(1) \text {, } \\
\text { //doi.org/ } \\
76 \text { 1.6064 }\end{array}$ \\
\hline $\begin{array}{l}\text { Copyright: } \\
\text { ( ) 2020. The } A \\
\text { Licensee: AOS } \\
\text { is licensed unc } \\
\text { Creative Comr } \\
\text { Attribution Lic }\end{array}$ & $\begin{array}{l}\text { Authors. } \\
\text { IS. This work } \\
\text { der the } \\
\text { mons } \\
\text { cense. }\end{array}$ \\
\hline Read online: & \\
\hline 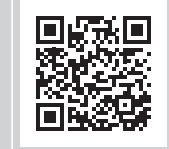 & $\begin{array}{l}\text { Scan this QR } \\
\text { code with your } \\
\text { smart phone or } \\
\text { mobile device } \\
\text { to read online. }\end{array}$ \\
\hline
\end{tabular}

We do not need 'the earth' as the space for encounter and cooperation between world religions in the way Moltmann suggests. Firstly, this fails to do justice to the contemporary situation concerning religious diversity: people from different religions have no problem in working together either for promoting ecological goals or for fighting them together. Within religions, there are often greater divergences between eco-friendly and anti-ecological adherents of that same religion. Secondly, Moltmann's proposal misguidedly confuses boundaries of beliefs and boundaries of grammar concerning religious diversity. Paying attention to religions as grammar provides a more accurate picture of the reality concerning world religions from an ecological perspective. In the final section of this article, I present some suggestions on moving forward in the debate about ecology from within this new perspective. We need to keep in mind that it is not religions but people who have opinions about ecology. The dialogue that needs to take place is not a high-level bureaucratic one between officials of different religions but one between people. In this grassroots-level discussion, it is important to listen to the other person rather than to consider him or her as a representative of his or her religion. We should not allow people to claim an entire religion for their position, dismissing others as revisionists. Religions are grammars that can express both eco-friendly and anti-ecological messages.

Contribution: This article contributes to an in-depth understanding of religious diversity; it proves the usefulness of the distinction between grammar and beliefs in the study of religion and demonstrates this using the case of ecotheology as an example.

Keywords: Religious pluralism; John Hick; Ecotheology; Ludwig Wittgenstein; Nature religions.

\section{Introduction}

'Do we need an "earth religion" as the overarching framework in which world religions can encounter one another and live side by side in harmony?', the renowned Christian theologian Jürgen Moltmann (2011:16) asked in an article on world religions from an ecological perspective. He did not explicitly answer his question but seemed to be sympathetic to the idea. As a distinguished Christian theologian, Moltmann did not propagate a new religion but argued that we need the theme of 'the earth' as the space for encounter and cooperation between world religions (Moltmann 2011:23). I wish to challenge this. I agree that the ecological crisis is serious and that we need to get as many people as possible on board to deal with it. I will argue, however, that there is a problem with the concept of an 'overarching framework' for religions, with the assumption that designating a particular space for encounter and cooperation is needed for religions to live together side by side, and with the assumption that it is religions rather than religious people who need to be addressed in connection with the ecological crisis.

Moltmann made his name as the theologian of hope. In his recent book The Spirit of Hope, in which he reprinted the article to which I referred above, he (Moltmann 2019) emphasises that:

$[I] \mathrm{n}$ the light of our faith, as Christians we can honestly assess and face the full force of humanity's contemporary challenges yet also experience and instil a realistic hope of transcending them. (p. viii)

Moltmann's colleague Johan Buitendag (2019b:2) notes that ecotheology is the focal point of Moltmann's entire theology and that the subtitle of The Spirit of Hope, 'Theology for a world in peril', sounds uncharacteristically negative. It is urgent that something happens now before it is too late. Moltmann is and remains a Christian theologian (see, e.g., Buitendag 2019b:1; Moltmann 2016b:41), but the enormity of the ecological crisis forces him to consider the level of all world religions as well. He dreams of a space of encounter and cooperation for world religions to come together. This is the context in which he even considers the idea of

Note: Special Collection entitled Theology and Nature, sub-edited by Johan Buitendag (UP). 
'a common earth religion' and an 'overarching framework in which world religions can encounter one another' (Moltmann 2011:16).

I admire Moltmann's activism for the cause of ecology. He may be very much on point when he argues that, '[e]cological theology is dealing not only with ecological questions but also with a reformation of the whole of Christian theology. A paradigm change, no less, is in process' (Moltmann 2016a:5). I take issue, however, with the role he assigns to religions rather than religious people in this respect. People, not religions, should be engaged to form an ecological response. I will argue this point by comparing the role of religions to the role of grammar in language.

Buitendag (2019a:17) compares Moltmann's ecotheology and the Earth Charter with grammar. However, Buitendag uses the comparison with grammar differently from the way I propose to use it in this article, as I will explain (for a discussion of other ways in which the concept of grammar is used in theology, e.g. by George Lindbeck, see Kroesbergen 2020). The Earth Charter Initiative (2000) published a document emphasising the importance of facing the ecological crisis:

$[\mathrm{W}] \mathrm{e}$ stand at a critical moment in Earth's history, a time when humanity must choose its future. [...] We must join together to bring forth a sustainable global society founded on respect for nature, universal human rights, economic justice, and a culture of peace. (n.p.)

Buitendag (2019a:7) notes the great convergence between this charter and Moltmann's position, and he proposes to see the Earth Charter as providing the grammar in the engagement of ecotheology and the natural sciences. Together with Moltmann (2016b:41), Buitendag emphasises the compatibility of the natural sciences and theology. The natural sciences provide the vocabulary and ecotheology provides the overarching framework or paradigm or grammar. Buitendag (2019a:17) uses the metaphor of 'grammar' here in contrast with 'vocabulary'. Together the vocabulary - the words - and the grammar - the rules - make up a language. I am not disputing the usefulness of this application of the metaphor 'grammar', but it is important to distinguish it from the way I will use the metaphor 'grammar' in this article.

Grammar and vocabulary make up a language, but with these two, still nothing has been said yet. People speak a language, they make statements in their different discourses with one another. I will contrast 'grammar' with this aspect of language: that which is being said in language, the beliefs that are expressed, the statements that are being made. One person may say 'it rains', another person may say 'Het regent' and yet another person may say 'Kuli moula' - they are all saying the same thing, but they are expressing it differently, according to a different grammar and vocabulary. The contrast between grammar (and vocabulary) on the one hand, and what is being said on the other hand, is what I am referring to when I propose to compare the role of religions with the role of grammar in language. In this article, I will argue that world religions are like grammar in this way, and that if they are, then Moltmann's proposal to look for an overarching structure or common space in which world religions can encounter each other to face the ecological crisis is misguided.

Firstly, I will show that inviting the world religions to join in a conversation about the ecological crisis, like Moltmann does, implies a misrepresentation of the situation at hand. Secondly, I will argue that considering world religions as grammar, in the sense described above, provides a (still crude but) more accurate picture of the issues that need to be addressed. Finally, I will propose a different way forward, one in which the Earth Charter is not the grammar of the dialogue, but rather the opposite, it phrases the desired beliefs to be expressed in one grammar or the other.

\section{Misguided description of the situation}

Moltmann (2011:23), in his article on world religions from an ecological perspective, proposes to see 'the earth as the space for encounter and cooperation between world religions'. In particular, he (Moltmann 2011:23) wants the world religions to no longer look down upon 'local nature religions' but to learn from their ecological wisdom and natural reverence. As an example of this wisdom, he (Moltmann 2011) tells a story he has heard from a friend in South Africa:

$[\mathrm{W}]$ henever his father wanted to make a canoe, my friend would have to chop down a tree. But in order to fell the tree, he would first have to ask the tree spirit for forgiveness. (p. 23)

Christian missionaries came and condemned this practice as idolatry, but now, environmentalists say that his friend was right after all.

Moltmann could have gathered this story much closer to home. Anthropologist James Frazer (1957:149), a century before, recounted these practices as still taking place in Austria and Germany. Similar practices are also on record for Britain, Libya, Indonesia, Siberia and Nigeria, for example. As an example to show the spiritual values of Africa, Orobator (2018) asks us to:

Consider, for example, the parent who goes to the forest to collect herbs and barks for preparing a healing remedy for a sick child. Before wielding the machete, he expresses contrition for the damage to be caused and pleads with the plant or tree for an efficacious outcome. Or a hunter who apologizes to game he has just caught and explains why he needs it for food so he and his family will survive. (p. 123)

Is Moltmann correct in arguing that world religions can learn from these practices that seem to have their home in nature religions the world over? First of all, it is important to be aware that these practices can mean different things.

Elsewhere, I (Kroesbergen 2005) discussed the practice of asking trees for forgiveness in response to Christian 
theologian Robert Jenson's (1999:113n) dismissal of ecotheology: '[r]ecent waves of "creation spirituality" are simply apostasy to paganism. And it is precisely such unguarded, even unargued, judgement that is required of the church'. Jenson and many others contrast Christianity and animism or nature religions in a very simplistic way. They argue that Christianity allows for scientific research of nature, as the historian of science and religion Ian Barbour (1966:47) says, 'the world was not an object of worship and thus could become an object of study'. Animism, on the other hand, does not, as Jenson (1999:115) says, 'one does not shoot rockets at the moon if one takes it to be a goddess'. I (Kroesbergen 2005) argued that practices like asking trees for forgiveness could be the expression of fear for the wrath of the nature spirits, but it could express a general attitude of reverence for nature as well, in a way that does not render scientific research impossible. In fact, the oppressive interpretation is most likely to be a degeneration of the more freehearted way of asking trees for forgiveness.

Of course, world religions could learn from this latter reverence for nature. Moltmann himself is an example of how a Christian could do so, but we can find similar tendencies already in the older traditions of Christian Celtic spirituality as well. I have not come across a ritual of asking trees for forgiveness in Celtic Christianity, but I would not be surprised if it existed. In the 1940s, George MacLeod revived Celtic spirituality on the island of Iona because '[h]e felt the Christian church exhibited little or no concern for the earth' (Duncan 2015:1). He builds a community with 'an ecological dimension in theology and practice', exhibiting 'love for God's creation and care for the environment' (Duncan 2015:1-2). As said, I do not know about tree felling, but concerning hunting Celtic Christianity had rituals to express that the hunter 'was not to take life wantonly' (Duncan 2015:8). The Christian community of Iona would have no problem learning from nature religions in the way Moltmann proposes.

Similarly, I once heard the well-known Muslim theologian Aref Ali Nayed tell a story about his youth (during the discussion after his paper at the Society for the Study of Theology Annual Conference 2006, Leeds). His grandmother in Libya had asked him to get some mint from the garden to use in cooking. Nayed did not know how to do so, and he uprooted an entire plant of mint. When he brought this to his grandmother, she got very angry and said, 'why did you not take just a few leaves?! Now, what are you going to tell this plant when you meet it during the Last Judgment?!' Nayed's and his grandmother's religion seems to seriously engage with the ecological perspective already, just like Moltmann (2011:24) proposes. They already 'reinterpret [...] preindustrial wisdom for our post-industrial age' (Moltmann 2011:23). In fact, Moltmann (2011:23-24) argues that the world religions' concern with the world beyond is a problem for ecotheology, but Nayed's grandmother showed that this very concern can be used in an ecotheological way just as well. It is not necessary that a focus on the world beyond, or the Last Judgment in this case, would lead to a 'negation of this worldly life' and a 'denial of earthly life', as Moltmann (2011:24) states. The same grammar (and vocabulary) of an afterlife can be used not only to express escapist, antiecological beliefs but also to express eco-friendly beliefs, as Nayed's grandmother showed.

The fact that Christianity and Islam could learn easily from nature religions in their reverence for nature may seem to support Moltmann's case, but actually it shows that Moltmann is not addressing the real problem concerning the ecological crisis. The Christians Moltmann and MacLeod, the Muslims Nayed and his grandmother and the adherents of nature religions of all times and places can easily encounter one another on the topic of ecology and live side by side in harmony and in reverence for nature, but that does not bring us one step closer to doing something about the ecological crisis. Moltmann's project of bringing together world religions in a common space (Moltmann 2011:23) or in an overarching framework (Moltmann 2011:16) misses the point and does not address where the real divergences are.

What it shows is that inter-religious dialogue between participants of different religions is fairly easy, as long as they share a cosmopolitan outlook and a concern for ecology, basic human rights and so on. It will be fairly easy to find people from all world religions agreeing on a sustainable global society founded on respect for nature, universal human rights, economic justice, a culture of peace and all the other things that the Earth Charter (2000) recommends. Even interreligious dialogue and exchange between participants of different religions who have a much less ecological, but more localist or nationalistic and conservative outlook is often fairly easy. This is a bit paradoxical, of course, as everyone here defends his or her own group, but, in general, these people also defend the right of other groups to defend themselves. They share a common enemy in the adherents of things like the Earth Charter, the globalist, liberal elite. Thirdly, we see that within the different particular religions, intra-religious dialogue between participants with a cosmopolitan, ecological, human-rights-based outlook and those with a non-ecological, nationalistic, conservative perspective is almost impossible.

This is connected to a phenomenon that is sometimes referred to as the 'two faces of religion' in our times. In academics as well as in politics, journalism and education, it has become quite common to distinguish two kinds of religion or two forms of religious affiliation, sometimes referred to as 'good religion' and 'bad religion', 'mature religion' and 'immature religion', or 'peaceful religion' and 'dangerous religion'. Discussing the governance of religion, Shakman Hurd (2015:22) mentions that the British Prime Minister Tony Blair in response to the $9 / 11$ attacks spoke about the 'two faces of faith' and that, currently, '[t]he 'two faces of faith' is a discourse that shapes the contemporary global governance of religious diversity'. International politics is no longer based on the secularisation thesis, but, Shakman Hurd (2015:23) 
continues, it presupposes that religion has two sides: '[b]ad religion, which is said to require discipline and surveillance', and good religion that should be encouraged for its potential in, for example, 'promoting the common international good through humanitarian relief' (Shakman Hurd 2015:24). Political scientist Connolly (2008) observes that the two sides of religion belong together:

$[T]$ his correlation between pluralization and fundamentalization is not accidental, for each conditions the other: each drive to pluralization is countered by a fundamentalism that claims to be authorized by a god or by nature. Moreover, any drive to pluralization can itself become fundamentalized. These two drives participate, therefore, in the same political matrix. (pp. 37-38)

The two faces of religion reinforce one another: looking for the supposed foundations of one's religion is a response to feeling lost in a globalising world, whereas observing the dangers of a narrow approach to one's religion encourages others to open up even more to like-minded people in other religions, like Moltmann is encouraging.

Well-known sociologist Ulrich Beck (2014) elaborates on these two faces of religion:

For all the humanity of religion there, too, is a totalitarian temptation inherent in it. Out of the universalism of religion there arises a cosmopolitan fraternity which transcends class and nation, but also demonization of religious others throughout history - fault lines that go back about two thousand years to the origins of the monotheistic religions, Christianity, Judaism, Islam. God can equally civilize and barbarize human beings. (p. 129)

In many discourses - from philosophy of religion to education to governance - the distinction between the two faces of religion is taken as self-evident. Philosopher of religion Marianne Moyaert (2018) summarises the main characteristics ascribed to the two kinds of religion:

[I]f good religion clusters with terms like authenticity, spirituality, interiority, faith, and reason as well as a peacefulness and openmindedness, bad religion is associated with formalism, dogmatism, ritualism, materialism, and irrationality as well as violence and closed-mindedness. (pp. 1-2)

She (Moyaert 2018) describes how, as an interreligious educator, this approach to religion:

$[E]$ nds up dividing my classroom into 'liberal, mature' students who seem to believe that they embody the virtue of openness and 'conservative, immature' students who, according to the first, still need to cover a considerable distance to become competent in dialogue. The latter's perspective and what they have to contribute to the conversation is simply not taken seriously. (p. 3)

The 'conservative, immature' students are considered to be not yet ready to take part in inter-religious dialogue so much so that they are a priori excluded from it.

Inter-religious dialogue often seems extremely successful, as long as all of the participants are like Moltmann, Nayed and freehearted adherents of nature religions. These Christians and Muslims are sometimes called 'liberal', but this may suggest that they consider themselves to some extent 'free' from their respective traditions. Most often, however, they see themselves as approaching the heart of their tradition. The concern for freedom that these people generally share is the concern for the freedoms and rights expressed in the Universal Declaration of Human Rights. Yet, they do not care about these freedoms and rights because these freedoms are in that declaration, but because they find a concern for these freedoms and rights at the core of their own traditions and they recognise very similar concerns in other traditions as well. The concern for ecology that these people share is a concern as it is expressed in the Earth Charter, but again, they find reasons to adhere to the ecological ideals not in this charter, but in their own tradition. Yet, because they all find a common cause in the fight for ecology, freedom, human rights, human dignity, compassion, etc., in their own traditions, inter-religious dialogue becomes fairly easy.

On the other hand, however, in almost all religious traditions, there are groups of people with a more localist, anti-ecological and conservative outlook. In his book The Age of Anger: A History of the Present, renowned essayist Pankaj Mishra (2017:86) traces the cosmopolitan outlook to Voltaire and the enlightenment: a heaven on earth of freedom and equality was to be created by anonymous and ruthless technocrats. This was accompanied, however, by a 'characteristically modern revolt against modernity', which has spread around the globe reflecting (Mishra 2017):

$[T]$ he quintessential inner experience of modernity for most people: the uprooted outsider in the commercial metropolis, aspiring for a place in it, and struggling with complex feelings of envy, fascination, revulsion and rejection. (p. 90)

According to Mishra (2017:110), the resulting revolt with its 'many "isms" of the right and the left - Romanticism, socialism, authoritarianism, nationalism, anarchism - can be traced to Rousseau's writings'. People 'feel left behind by the globalized economy or contemptuously ignored by its slick overlords and cheerleaders in politics, business and the media' (Mishra 2017:274), they see 'the metropolis [as] a den of vice and that virtue resided in ordinary people (whom the elites routinely conspired against and deceived)' (Mishra 2017:110), and, referring to Rousseau, long for 'a return to the collective, the "people"' (Mishra 2017:111). Despite the particularity of the dreams of making the United States of America great again, to take back control over Britain, to recreate organic life in the single state of Russia and to build a nation-state specifically for the Jews or Hindus, there is much exchange of ideas between these groups. There are global movements of anti-globalists.

Beck (2010:174) notes that '[t]hose who proclaim an anticosmopolitan fundamentalism are compelled to act from within the terrain of cosmopolitanism', and concludes that 'we must speak of cosmopolitan anti-cosmopolitanism'. 
He (Beck 2010) observes that these global anti-globalists or fundamentalist movements share:

$[F]$ our main distinguishing features: (1) the rediscovery of unquestioning acceptance; (2) the unwavering belief in the totalitarian immediacy of God; (3) the demonization of believers in other faiths and none; and (4) transnational networks and operations. (p. 170)

I propose that we can add a disdain for ecological concerns as a fifth trend that these various movements have in common. Those who deny global warming or human influence on global warming can be found amongst these groups. The connections across the borders of their own idealised identity are an intrinsic part of these cosmopolitan anti-cosmopolitans. A French member of one such group, the identitarians, Alain de Benoist, 'simultaneously defends a Muslim immigrant's right to wear the veil and opposes the immigration policies that allowed her to settle in France in the first place' (Chatterton Williams 2017). It is the idea that every tradition or religion should have a right to self-determination and purity, which allows for the mutual respect of having a shared enemy, and for - however, paradoxical it may seem inter-traditional and inter-religious dialogue and exchange of ideas amongst nationalist conservatives. The US President Donald Trump recently echoed this sentiment when he stated in an address to the United Nations, '[t]he future does not belong to the globalists. The future belongs to the patriots' (Borger 2019).

In pleas for inter-religious dialogue, like that of Moltmann, it is often assumed that intra-religious dialogue is easy. In a debate involving different religions, it may be hard to find common criteria, whereas, as Clayton (2006:5) suggests, within one religious tradition, this is different: ' $[w]$ hat count [sic] as "good reasons" may be predominantly tradition-specific, as would the mechanism whereby a dispute could be resolved'. He (Clayton 2006:5) gives the example of 'citing from authoritative scriptures'. It is true that within Christianity, for example, citing the Bible is an important way to support one's position - the authority of the Bible is an important part of Christian grammar - in practice, however, I have not often seen this as ensuring that disputes are resolved. There is an old Dutch saying that every heretic has his text: everyone in any dispute within Christianity can find Bible verses to support his or her opinion. It is not only in the debate about ecology, but also in disputes about homosexuality, women on the pulpit, drinking alcohol, prophecy, the prosperity gospel, abortion, sex before marriage, capitalism, masturbation, weapons of mass destruction, anointing oil, children at Holy Communion, and so on and so forth: both sides agree that the Bible is authoritative, but it does not help to resolve the disputes. And this is not specific to Christianity; in Islam, nature religions and any other religion, you will find a similar situation. Intra-religious dialogue proves to be just as impossible as inter-religious dialogue is assumed to be in much literature on religious diversity.
'Do we need an "earth religion" as the overarching framework in which world religions can encounter one another and live side by side in harmony?', Moltmann (2011:16) asked. My answer is 'no'. We do not need an overarching framework for world religions because (1) eco-friendly members of different world religions already have no problem in encountering one another and living side by side in harmony; (2) nationalistic, anti-ecological members of different world religions have no problem in encountering one another and living side by side in harmony either; and (3) within different world religions, sharing one overarching framework does not help eco-friendly and anti-ecological members of particular religions encounter one another and live side by side in harmony. Moltmann's plea concerning world religions from an ecological perspective fails to do justice to these realities. So what might be a more accurate picture of the issues that need to be addressed in this respect?

\section{World religions as grammars}

If somebody tells me that he or she is a Christian or a Muslim, I know much about what concepts and stories he or she will use - their language or grammar - but significantly less about their opinions or beliefs. I know that they will speak of either the Bible or the Quran as the word of God, but not what this way of speaking means to them, which beliefs about the world follow from it. I do not know their position concerning ecology or homosexuality, for example. I know about the grammar (and vocabulary) they will use, but not about their beliefs, so I would say.

Most scholars on religious diversity pay lip service to the importance of religion as grammar by mentioning concepts like 'perspective', 'world view' or 'conceptual scheme', yet they continue by treating religion as grammar as itself enshrining particular beliefs about the world. Here, I will argue that world religions from an ecological perspective and also the broader debate about religious diversity would benefit from making a stricter distinction between grammar and beliefs.

Moltmann's proposal to bring the world religions together in one overarching space or framework is reminiscent of the theories of John Hick. In fact, the terms of many discussions on religious diversity have been set by Hick (1985:39), defending what he calls the 'pluralistic hypothesis'. Even though there have been many different interpretations of pluralism since Hick presented his version - "“[p]luralism” is Hydra-like in its growth', as Gavin D'Costa (2016:137) notes Harrison (2015:260) observes that 'John Hick's version remains the most well-known and influential pluralist theory to date'. Hick (2004) describes his form of pluralism as follows:

[T] he great world faiths embody different perceptions and conceptions of, and correspondingly different responses to, the Real from within the major variant ways of being human; and that within each of them the transformation of human existence 
from self-centredness to Reality-centredness is taking place. (p. 240)

When discussing the absolute claims that, according to Hick (1985:46), are made by religions, he proposes to treat 'the truth-claim and the salvation-claim [...] as a single package'. He (Hick 1985) continues using this metaphor, stating that:

The valuable contents of this package, the goods conveyed, consist in salvation or liberation; and the packaging and labelling, with the identifying of the sender and the directing of the package to the recipient are provided by the doctrine. Thus the doctrines are secondary, and yet essential to the vital matter of receiving salvation, somewhat as packaging and labelling are secondary and yet essential to transmitting the contents of a parcel. (p. 46)

The different religions are the essential but secondary packaging or grammar. They are not identical with but are containing the essential thing: salvation and truth.

In his work, Hick (1995) uses the common distinction between exclusivism, inclusivism and pluralism, although he also says that inclusivism is difficult to conceptualise:

In order to make sense of the idea that the great world religions are all inspired and made salvific by the same transcendent influence we have to go beyond the historical figure of Jesus to a universal source of all salvific transformation. Christians may call this the cosmic Christ or the eternal Logos; Hindus and Buddhists may call it the Dharma; Muslims may call it Allah; Taoists may call it the Tao; and so on. But what we then have is no longer (to put it paradoxically) and exclusively Christian inclusivism, but a plurality of mutually inclusive inclusivisms which is close to the kind of pluralism I want to recommend. I am suggesting in effect that religious inclusivism is a vague conception which, when pressed to become clear, moves towards pluralism. (p. 23)

Quinn and Meeker (eds. 2000) in their anthology on The Philosophical Challenge of Religious Diversity also note about inclusivism that:

$[A]$ lthough many hold this view, no one has yet undertaken to provide the same detailed defense of inclusivism that is evident in Hick's defense of pluralism or Alston's defense of exclusivism. (p. 27)

Quinn and Meeker (eds. 2000:27) conclude that 'inclusivism faces a less certain future'.

We are left with exclusivism and pluralism: exclusivism considering only one's own religion as true, and pluralism allowing for the possibility that different religions are all partial descriptions of an ineffable religious Real. If we translate this back to Moltmann's (2011:16) proposal: the real earth is the space for encounter and cooperation between all the different world religions. All religions have their own perspectives on life and reality, but ultimately, it must refer to the one shared earth. Hick's (1985:37) idea has often been illustrated with the parable of blind people feeling an elephant. It is impossible to tell which religion is correct because there is no ultimate perspective available from which to view the blind people feeling the elephant, as yet at least.

Hick (1985:125) wants to uphold 'the basically factual character of religious understandings of the universe' by introducing what he calls 'the principle of eschatological verification'. For now, we do not know which religion is right and to what extent, but at the end of times in the eschaton, we can check. Hick (1985:125) admits that '[i]t is probably not [...] directly relevant to the assessment of the conflicting truth-claims of the various traditions', but through the concept of eschatological verification, he wishes to acknowledge what he takes to be a fact: that religions make truth claims. Moltmann (2011:17) makes the same assumption by arguing that '[i]deological and religious claims to absolute truth must be relativized for the sake of the future of humankind'. Both Hick and Moltmann presuppose that world religions make truth claims, often conflicting truth claims, and they try to mitigate between these religions by placing them within a broader overarching space or framework. It may seem common to say that religions make (often conflicting) truth claims, but this is impossible if religions are grammar.

When considering the topic of truth claims, Hick (1995:23) sets out by stating that '[i]t's undoubtedly the case that the great world faiths have developed very different beliefsystems'. This shows that Hick wants to have it both ways. On the one hand, he claims that he treats different religions as different languages, or grammars, or frames of reference, or forms of experiencing-as - the latter expression referring to Ludwig Wittgenstein's concept of 'seeing-as', famously illustrated by the duck-rabbit picture that can be seen as either a duck or a rabbit. On the other hand, Hick discusses the different salvation claims and truth claims of religions, trying to show how they can all be faithful descriptions of the one big Real that goes beyond human understanding. He conflates grammar and beliefs. Hick (1985:26) describes the believer as someone who is 'trusting that the religious way of experiencing as into which he or she has entered will ultimately be vindicated by the future unfolding of the character of the universe'. A pluralist assumes that other religious grammars or forms of experiencing-as may prove to be true as well - one describing the trunk of the elephant, the other one its body - but to be a believer, for Hick, means to trust that one's own perspective will turn out to be - at least partially - correct. But how can a perspective or grammar be correct - or incorrect for that matter - if judgements about what is correct and not are always made within a particular perspective or grammar?

If we return to the duck-rabbit example, we see that Hick has diverted quite a bit from Wittgenstein here. Someone who sees the duck-rabbit picture as a duck is not hoping for 'future vindication', let alone 'eschatological verification' - one does not state that one sees a duck in the hope that in the future, it will turn out to be really a duck; however, he or she is simply 
reporting his or her perception, as Wittgenstein emphasises: this person sees a picture of a duck. Wittgenstein introduces the duck-rabbit picture in a discussion of two kinds of seeing: seeing different faces and seeing the likeness between these different faces. The latter he (Wittgenstein 2009:PPF \#115) calls 'seeing an aspect' and he wants to clarify 'the concept and its place among the concepts of experience'. For Wittgenstein, seeing an aspect is an experience, not a truth claim. We judge truth claims based on our experiences. It makes no sense to judge experiences, unless at that time other experiences, rules and statements stand fast for us. Seeing in general and seeing an aspect are part of what we do not doubt when we discuss reality. We can only doubt these in special circumstances from within another perspective, another grammar, that we do not doubt. We determine the truth or falsehood of a belief about reality from within a particular system of rules and statements that we accept as a matter-of-course foundation. In ordinary circumstances, we do not doubt our experiences or what we see, just like we do not doubt our grammar.

Wittgenstein (1969) gives the example of the chemical investigations of Lavoisier:

Lavoisier makes experiments with substances in his laboratory and now he concludes that this and that takes place when there is burning. He does not say that it might happen otherwise another time. He has got hold of a definite world-picture [Weltbild] - not of course one that he invented; he learned it as a child. I say world-picture and not hypothesis, because it is the matter-of-course foundation of his research and as such goes unmentioned. (p. 167)

To say that 'what happens when there is burning at this time and place will happen when there is burning at other times and places as well' is not to make a statement of fact or a hypothesis, but it is expressing a part of the world picture that is assumed in doing experiments. It is part of the grammar, and therefore, not of the beliefs. Unlike Hick, Wittgenstein was emphasising the distinction between truth claims, hypotheses, theory or beliefs, on the one hand, and grammar, language, picture or perspective, on the other hand. The distinction is fluid and moving, but it is always there - in one way or another - and it is important. Wittgenstein (1969) uses the image of a river:

I distinguish between the movement of the waters on the riverbed and the shift of the bed itself: though there is not a sharp division of the one from the other. (p. 97)

Even though the distinction is not clear-cut or sharp or stable, grammar and changes in grammar can be distinguished from beliefs and changes in beliefs. The fact that there is no sharp line does not mean that there is no distinction. It is necessary to acknowledge this distinction between grammar and beliefs if we want to account for the current conditions of religious diversity and inter-religious dialogue.

For Hick, different religions are like different languages or grammars or forms of experiencing-as - within these languages truth claims are being made as usual. Hick (1985:26), however, treats the languages or grammars or forms of experiencing-as as a whole also as making truth claims, as expressing statements of belief. It is not merely believers who make truth claims using the grammar of their particular religion, but Hick (1985:125) speaks about 'the conflicting truth-claims of the various traditions', and considers it to be undoubtedly the case that the great world faiths have developed very different belief systems which make different truth claims accordingly. If we use Christianity and Islam as an example, for Hick, the boundaries between religions are both boundaries of grammar - Christians and Muslims speak in different ways - and boundaries of belief Christians and Muslims believe different things about the world at the same time. Hick's perspective can be expressed as shown in Figure 1.

Once we separate grammar and beliefs, however, a very different picture of the situation is possible as well (see Figure 2).

Upholding the distinction between grammar and beliefs as shown in Figure 2 would reshape the debate on religious diversity and ecology significantly. Christians and Muslims clearly use a different grammar: one speaks of Jesus as the Son of God, whilst the other does not; the authority of Jesus is higher than the authority of the Bible, in a way that the authority of Muhammad does not supersede the authority of the Quran, and so on. Christians and Muslims use different systems of rules and statements in what they say - the grammar is different - yet what they express in each their own grammar may be remarkably similar in particular cases. The beliefs of one Christian about ecology may be much closer to the beliefs of some Muslims than they are compared to some fellow-Christians. With Christians he or she may share the grammar, but in beliefs about ecology, some Muslims may be closer.

A Christian related to the Iona community performs rituals to ensure one's life to be an expression of love for God's creation and care for the environment; a Muslim lady tells

\begin{tabular}{|l|l|l|}
\hline \multicolumn{2}{|c|}{ Boundary of grammar } & Boundary of beliefs \\
\hline Christians (eco-friendly) & & Muslims (eco-friendly) \\
Christians (anti-ecological) & & Muslims (anti-ecological) \\
\hline
\end{tabular}

FIGURE 1: John Hick.

\begin{tabular}{|l|l|}
\hline \multicolumn{2}{|c|}{ Boundary of grammar } \\
\hline Christians (eco-friendly) & Muslims (eco-friendly) \\
\hline Boundary of beliefs & \\
\hline Christians (anti-ecological) & Muslims (anti-ecological) \\
\hline
\end{tabular}

FIGURE 2: New proposal. 
her grandson not to uproot mint plants for he will have to face this mint plant when Allah conducts the Last Judgment; likewise, if we add nature religions, a modern Pagan asks a tree for forgiveness before felling it. There are boundaries of grammar between them but boundaries of beliefs not so much. Within each of their religions, these believers may find much stronger opponents (except maybe for the Pagan), and these opponents may find each other in sharing a common enemy: the so-called globalist, liberal elite. This second picture in Figure 2 that allows for a real distinction between grammar and beliefs makes it possible to do more justice to the actual state of affairs concerning religious diversity than Moltmann's proposal. In the previous section, we noted that the problem with Moltmann's proposal is that it fails to do justice to the fact that eco-friendly members of different world religions already have no problem in encountering one another and living side by side in harmony; nationalistic, anti-ecological members of different world religions amongst one another neither; yet, within different world religions, sharing one overarching space or framework in the Bible or the Quran, for example, does not help eco-friendly and antiecological members of those particular religions to genuinely meet one another. All of these aspects are taken care of if we replace Hick and Moltmann's picture represented in Figure 1 with the picture in Figure 2. Now, if we use this new picture, what is the way forward concerning the world religions from an ecological perspective? If the world religions are the grammar, where does that leave the Earth Charter? To this we will turn in the final section of this article.

\section{Another way forward}

Although in particular cases it is often extremely difficult to disentangle what belongs to grammar and what belongs to beliefs, making a distinction between the two is necessary to account for the relative easiness of inter-religious dialogue between both eco-friendly Christians and Muslims, and anti-ecological Christians and Muslims.

If somebody tells me his or her religion, I know what words and images they will use, but not what this way of speaking means to them, which beliefs about the world follow from it. I know about the grammar (and vocabulary) they will use, but not about their beliefs, about ecology, for example. Beliefs cannot be found in grammar, people express their beliefs in grammar and it is not uncommon that such beliefs expressed within the same grammar are diametrically opposed to one another. People may share one religion or grammar, but have widely divergent perspectives on ecology, for example. Therefore, people should be engaged with such topics, and not religions, as Moltmann suggests.

According to Moltmann (2011:23), we need 'the earth' as the space for encounter and cooperation between world religions. He even suggests the need for an overarching framework to mediate between different world religions concerning ecology (Moltmann 2011:16). Such a kind of ecumenism of world religions requires high-level, bureaucratic deliberations resulting in noble but abstract documents like the Earth Charter. Elsewhere I (Kroesbergen 2018a) have shown that within Christianity in the context of Southern Africa, this kind of ecumenism is no longer feasible or necessary. Another kind of ecumenism has arisen: a grassroots ecumenism in which rather than drafting abstract overarching frameworks, people encounter one another and live side by side with whomever they find nearby (Kroesbergen 2019):

$[T]$ here is an ecumenical, wide and open-ended community of Christians beyond restricting and divisive institutions [...] relationships are informal and institutions have lost their value; the community of the church has become a diverse, multifaceted band of pilgrims, all journeying, however imperfectly, together towards God. (p. 276)

Instead of looking for spaces of encounter and cooperation between world religions, a similar grassroots trajectory might be a more feasible perspective for world religions facing the ecological crisis as well. Instead of looking at the patchwork of world religions, it is more important to look at people. People do not need to speak the same grammar to understand one another, or even agree with one another.

Whether one says 'it rains', 'Het regent' or 'Kuli moula', people are saying the same thing even though they use different grammars and vocabularies. One may try to formulate the belief that is expressed in these different statements more objectively, for example, ' $\mathrm{H}_{2} \mathrm{O}$ is drawn with force $g$ towards the third planet orbiting the sun'. This is still in English, but it no longer has the cultural associations of 'rain' - the songs and stories about rain that may come to mind and so on. It phrases the belief expressed by 'it rains' or 'Kuli mvula' more neutrally. Similarly, the Earth Charter would not be the grammar of discussions about ecology, but a neutral formulation of beliefs about the importance of the environment that can be expressed in the different grammars of the different world religions. The Christian performing rituals to ensure her love for God's creation, the Muslim speaking about the Last Judgment to warn against uprooting mint plants and the modern Pagan asking trees for forgiveness all use different grammars but they express the belief in the importance of 'a sustainable global society founded on respect for nature', as it is said in the Earth Charter (2000).

The concern for ecology that these people share is a concern as expressed in the Earth Charter (2000). I mentioned above that they find the reasons to adhere to these ecological ideals not in this charter, but within their own tradition. Moltmann in his work gives many examples from within the Christian tradition; for example, he (Moltmann 2011:24) makes much of the concept of the Sabbath from the Hebrew Bible. At times, however, Moltmann suggests that he proposes for the world religions like Christianity themselves to change: they should 'metamorphose into earth religions', he (Moltmann 2011:23) says. I think that there are two problems with this suggestion. Firstly, it misunderstands how religions are grammars: the world religions in themselves are not pro-earth or anti-earth, but it would be good if people who 
use the grammar of world religions to express themselves became earth-people. Secondly, it misguidedly assumes that these earth-people in the different world religions have diverted from their own religion in its original form. This is neither tactically prudent in the discussions amongst pilgrims of many different kinds, nor true. I wish to illustrate this by returning to the example of asking trees for forgiveness that Moltmann (2011:23) uses.

When anthropologist Frazer gives examples of people who ask trees for forgiveness before felling them, he (Frazer 1957:154) tells us a story from Sumatra, at the time part of the Dutch Indies. The Mandelings on Sumatra did not ask trees for forgiveness, but they tried to shift the blame for what they were doing. Before felling a tree, they would show it a fake letter from the Dutch authorities that they are forced to clear the area of trees. They would say, '[y]ou hear that, spirits. I must begin clearing at once, or I shall be hanged' (Frazer 1957:154). So, if the tree spirit would be angry, it should be angry with the Dutch government and not with the Mandelings.

Contemporary anthropologist Rane Willerslev (2013:49-54) describes a similar practice amongst the Yukaghirs in Siberia during the bear hunt. They would explain to the bear that they shot that it was actually the Russians who had killed it. Willerslev tells us, however, that he was surprised to find that the Yukaghirs did this in a joking manner. He concludes that they themselves did not fully take this practice seriously. Willerslev's colleague Eduardo Viveiros de Castro (2015:14) responds that this may be the case but this must be a later development; otherwise, so he says, 'first they have had to go to [sic] the trouble to invent (or discover) those spirits one wonders if it was just to have something to make fun of!' It does not make sense to assume that they came up with a belief in the wrath of the bear spirit, just to joke about it. There are two problems with this argument. Firstly, it is problematic to assume, as Viveiros de Castro (2015) does, that people at some point must have invented or discovered spirits in nature, as if before that they must have treated nature in a naturalistic way. Like philosopher of religion Mikel Burley (2018:62) argues, 'it is far from evident why any non-religious conception of mountains should be regarded as, necessarily, logically prior to a conception that includes this inherently religious element'. A naturalistic interpretation of bears may have been a later invention.

Secondly, Viveiros de Castro (2015) may be correct in dismissing Willerslev's (2013) idea that the joking context is primary to the rituals of the bear hunt, but Viveiros de Castro's suggested alternative that the Yukaghirs originally believed the bear spirit to be ontologically real does not make much sense either. As I (Kroesbergen 2005:397) argued elsewhere, it is not likely that a belief in tree spirits arises together with the means for how not to be bothered by them. Rather, as a philosopher of religion, D.Z. Phillips (1996) phrases it:

$[T]$ he hunters have a sense of the mystery of life and hence of a life ended. This is expressed in the ritual. It shows their sense of the animal's life and the seriousness of ending it. (p. 170)
As I mentioned before, the oppressive interpretation of asking trees for forgiveness is most likely a degeneration of the more freehearted way. Therefore, it is not true that earthpeople in the different world religions have diverted from their own religion in its original form. This is connected to a broader point about the history of religion as well.

A common interpretation of the history of religion is that first everyone believed literally in ephemeral beings in trees and God as a man with a beard above the clouds and so on, then science came along and showed it was wrong, and then by an incredible stroke of luck, it turned out that everything could be re-interpreted in a freehearted response to the world way as well. Another reading of history is also possible, however: firstly, everyone believed in a freehearted response to the world way, then science came along and was very successful, and some believers tried to prove that their ways of speaking were just as important and claimed that their responses to the world were also true in the dumb sense. As I (Kroesbergen 2019:76) argued elsewhere, I consider the second course of events more plausible; literalistic beliefs represent a degeneration of faith. Religion was not a failed attempt at science (cf. Kroesbergen 2018b). To speak of the Last Judgment has always been intended to speak of how to behave in our this-worldly environment like Nayed's grandmother did. It was never meant to be a 'negation of this-worldly life' and a 'denial of earthly life' by putting forward hypotheses about some mysterious event in the future.

Instead of entering into a debate about history, however, it is enough not to accept the first interpretation of history too easily. Accepting this first interpretation is neither a prudent strategy in furthering the ecological cause nor necessary. There are different grammars like speaking of the Last Judgment or asking trees for forgiveness, and these grammars are used to express different beliefs: some ecofriendly, some negating earthly life; some fearful and quasiscientific about ephemeral beings in trees, some freehearted, expressing the mystery of life. In the many discussions going on about these beliefs, it would be putting yourself at a disadvantage to present your own position as a revisionist, as Moltmann (2016a:7) does when he urges Christians to leave their 'traditional gnostic spirituality' and replace it with 'seeing that the earth is our home'. This does not need to be presented as revisionary because the latter perspective has always been as much a part of Christianity as the former. There is no problem and has never been a problem in expressing ecologically aware beliefs in Christianity, Islam or whatever world religion one may adhere to. World religions are the grammars that are being used by people, people use these grammars to express their beliefs and these people's beliefs (rather than the religions) may be either ecofriendly or anti-ecological.

People do not need an abstract place for encounter and cooperation between world religions or even an 'earth religion' as the overarching framework in which world religions can live side by side in harmony, as people are 
already encountering one another and are already living side by side, sometimes in harmony and sometimes in conflict. Changing the grammar will not help in this respect. The only way forward is to engage each other's beliefs expressed in their grammars. Religions do not say things, people say things. It is the people and the truth claims that they are making that one should try to understand. The different religions from which they speak do not represent different beliefs about reality, but are different viewpoints within one and the same reality, to paraphrase a statement by Phillips (2001:322). Believers of different religions adopt these viewpoints to make their statements and truth claims about reality. It is important for religious diversity to carefully distinguish between what belongs to a grammar and what belongs to beliefs.

In day-to-day life, this approach translates into not treating people as representatives of their religion, but paying attention to each one's idiosyncrasy. This does not mean that everybody has the same capacity for independent thought. In most of our opinions, everybody simply follows others. For religious people, these others will often belong to their own religion, but that does not mean that they are following their religion: they are following particular people within their religion and not others. Using the same religion or grammar, very different opinions will have been expressed as well. Living in a context of religious diversity, mutual respect does not mean that we accept the other's faith as his or her belief system, but that we allow the other to be who he or she wants to be, including both how he or she follows the opinions of many of their fellow believers and how they choose to divert. We should listen to what the other is telling us, this particular person at this particular time and place, instead of focussing on the particular grammar - be it Christian, Muslim or Pagan - in which what he or she has to say is expressed. We should not lock people up in their identities, but we should listen to what someone says within the hubbub of voices and grammars. Instead of looking for abstract spaces of encounter between world religions or building overarching frameworks, we need to re-open communication between people who are in favour of ecotheology or creation spirituality and those who are opposed to it, whatever religion they belong to, whatever grammar they use (Kroesbergen 2014).

\section{Conclusion}

I have argued that we do not need 'the earth' as the space for encounter and cooperation between world religions in the way Moltmann suggests. Firstly, this fails to do justice to the contemporary situation concerning religious diversity: people from different religions have no problem in working together either for promoting ecological goals or for fighting them together. Within religions, there are often greater divergences between eco-friendly and anti-ecological adherents of that same religion. Secondly, Moltmann's proposal misguidedly confuses boundaries of beliefs and boundaries of grammar with respect to religious diversity. Paying attention to religions as grammar provides a more accurate picture of the reality concerning world religions from an ecological perspective. In the final section of this article, I presented some suggestions on moving forward in the debate about ecology from within this new perspective. We need to keep in mind that it is people but not religions who have opinions about ecology. The dialogue that needs to take place is not a high-level bureaucratic one between officials of different religions but one between people. In this grassroots-level discussion, it is important to listen to the other person rather than to consider him or her as a representative of his or her religion. We should not allow people to claim an entire religion for their position, dismissing others as revisionists. Religions are grammars that can naturally express both eco-friendly and anti-ecological messages. Using the case of ecotheology as an example, this article has shown that the distinction between grammar and beliefs in the study of religion leads to an in-depth understanding of religious diversity.

\section{Acknowledgements Competing interests}

The author declares that he has no financial or personal relationships that may have inappropriately influenced him in writing this research article.

\section{Author's contributions}

H.K. is the sole author of this research article.

\section{Ethical considerations}

This article followed all ethical standards for research without direct contact with human or animal subjects.

\section{Funding information}

This research was funded by the Senior Postdoctoral Fellowship provided by the University of Pretoria.

\section{Data availability statement}

Data sharing is not applicable to this article as no new data were created or analysed in this study.

\section{Disclaimer}

The views and opinions expressed in this article are those of the author and do not necessarily reflect the official policy or position of any affiliated agency of the author.

\section{References}

Barbour, I.G., 1966, Issues in science and religion, Harper \& Row, New York, NY.

Beck, U., 2010, A God of one's own: Religion's capacity for peace and potential for violence, transl. R. Livingstone, Polity, Cambridge.

Beck, U., 2014, 'The two faces of religion', in U. Beck (ed.), Ulrich Beck: Pioneer in cosmopolitan sociology and risk society, pp. 129-142, Springer, New York, NY.

Borger, J., 2019, 'Donald Trump denounces "globalism" in nationalist address to UN', The Guardian, viewed 25 April 2020, from https://www.theguardian.com/usnews/2019/sep/24/donald-trump-un-address-denounces-globalism. 
Buitendag, J., 2019a, 'Die Klub van Rome (“Club of Rome”) se soeke na planetariese welsyn beskou deur die oë van ' $n$ Gereformeerde teoloog', LitNet Akademies 16(3), 20

Buitendag, J., 2019b, 'Jy moet die aarde liefhê soos jouself', LitNet Akademies 16(3), 16.

Burley, M., 2018, 'Wittgenstein and the study of religion: Beyond fideism and atheism', in M. Burley (ed.), Wittgenstein, religion and ethics: New perspectives from philosophy and theology, pp. 49-76, Bloomsbury, London.

Chatterton Williams, T., 2017, 'The French origins of "You will not replace us": The European thinkers behind the white-nationalist rallying cry', The New Yorker, viewed 17 August 2020, from https://www.newyorker.com/ magazine/2017/12/04/the-french-origins-of-you-will-not-replace-us.

Clayton, J., 2006, 'Claims, contexts and contestability', in J. Clayton (ed.), Religions, reasons and Gods: Essays in cross-cultural philosophy of religion, pp. 1-12, Cambridge University Press, Cambridge.

Connolly, W.E., 2008, Democracy, pluralism and political theory, S.A. Chambers \& T. Carver (eds.), Routledge, Abingdon.

D'Costa, G., 2016, 'Changing the typology? Why pluralism should be renamed postChristian inclusivism', in E.J. Harris, P. Hedges \& S. Hettiarachchi (eds.), Twentyfirst century theologies of religions: Retrospection and future prospects, pp. 128-141, Brill-Rodopi, Leiden.

Duncan, G., 2015, 'Celtic spirituality and the environment', HTS Teologiese Studies/ Theological Studies 71(1), Art. \#2835, 10 pages. https://doi.org/10.4102/hts. v71i1.2835

Earth Charter Initiative, 2000, The Earth Charter, viewed 27 April 2020, from https:// earthcharter.org/virtual-library2/the-earth-charter-text.

Frazer, J.G., 1957, The golden bough: A study in magic and religion, vol. 1, Abridged edn., Macmillan, London.

Harrison, V.S., 2015, 'Religious pluralism', in G. Oppy (ed.), The Routledge handbook of contemporary philosophy of religion, pp. 257-269, Routledge, Abingdon.

Hick, J., 1985, Problems of religious pluralism, St. Martins, New York, NY.

Hick, J., 1995, A Christian theology of religions: The rainbow of faiths, Westminster John Knox Press, Louisville, KN.

Hick, J., 2004, An interpretation of religion: Human responses to the transcendent Springer, New York, NY.

Jenson, R.W., 1999, Systematic theology: The works of God, vol. 2, Oxford University Press, New York, NY.

Kroesbergen, H., 2005, 'Scheppingsleer vs. animism. Vergeving vragen aan bomen: Over geloofstaal', Bijdragen; International Journal in Philosophy and Religion 66(4), 379-401. https://doi.org/10.2143/BIJ.66.4.2004376

Kroesbergen, H., 2014, 'Ecology: Its relative importance and absolute irrelevance for a Christian: A Kierkegaardian transversal space for the controversy on eco-theology', HTS Teologiese Studies/Theological Studies 70(1), Art. \#2719, 8 pages. https://doi. org/10.4102/hts.v70i1.2719
Kroesbergen, H., 2018a, 'Radical change in Zambia's Christian Grassroots Ecumenism', Journal of Southern African Studies 44(2), 331-343. https://doi.org/10.1080/030 57070.2018.1424469

Kroesbergen, H., 2018b, 'An absolute distinction between faith and science: Contrast without compartmentalization', Zygon 53(1), 9-28. https://doi.org/10.1111/zygo. 12396

Kroesbergen, H., 2019, The language of faith in Southern Africa: Spirit world, power, community, holism, AOSIS, Cape Town.

Kroesbergen, H., 2020, 'God regulates the church, even if He doesn't - Wittgensteinian philosophy of religion and realism', Philosophical Investigations 43(3), 254-283. https://doi.org/10.1111/phin.12240

Mishra, P., 2017, Age of anger: A history of the present, Allan Lane, New York, NY.

Moltmann, J., 2011, 'A common Earth religion: World religions from an ecological perspective', The Ecumenical Review 63(1), 16-24. https://doi.org/10.1111/j.1758 6623.2010.00089.x

Moltmann, J., 2016a, 'The future of theology', The Ecumenical Review 68(1), 3-13. https://doi.org/10.1111/erev.12198

Moltmann, J., 2016b, Hoffen und Denken, Neukirchener Verlagsgesellschaft, Neukirchen-Vluyn.

Moltmann, J., 2019, The spirit of hope. Theology for a world in peril, John Knox Press, Westminster.

Moyaert, M., 2018, 'Interreligious learning, Ricoeur, and the problem of testimonia and hermeneutical injustice', paper presented at the European Society for Philosophy of Religion conference in Prague, 30 August.

Orobator, A.E., 2018, Religion and faith in Africa: Confessions of an animist, Orbis, Maryknoll, New York, NY.

Phillips, D.Z., 1996, Introducing philosophy: The challenge of scepticism, Blackwell, Oxford.

Phillips, D.Z., 2001, Religion and the hermeneutics of contemplation, Cambridge University Press, Cambridge.

Quinn, P.L. \& Meeker, K. (eds.), 2000, The philosophical challenge of religious diversity, Oxford University Press, Oxford.

Shakman Hurd, E., 2015, Beyond religious freedom: The new global politics of religion Princeton University Press, Princeton, NJ.

Viveiros de Castro, E., 2015, 'Who is afraid of the ontological wolf?: Some comments on an ongoing anthropological debate', The Cambridge Journal of Anthropology 33(1), 2-17. https://doi.org/10.3167/ca.2015.330102

Willerslev, R., 2013, 'Taking animism seriously, but perhaps not too seriously?', Religion and Society: Advances in Research 4(1), 41-57. https://doi.org/10.3167/ arrs.2013.040103

Wittgenstein, L., 1969, On certainty, Basil Blackwell, Oxford.

Wittgenstein, L., 2009 [1953], Philosophical investigations, in P.M.S. Hacker \& J. Schulte (eds.), 4th edn., transl. G.E.M. Anscombe, Wiley-Blackwell, Malden, MA. 